\title{
The Relation between Human Resource Management (HRM) Strategies and Job Loyalty as Practiced at the Public Relations (PR's) Units in the Government Ministries of Jordan
}

\author{
Akif Lutfi Al-Khasawneh \\ Department of Financial \& Administrative Sciences \\ AL-Huson University College, AL-Balqa' Applied University, Irbid, Jordan \\ P. O. Box 50, AL-Huson, 21510, Jordan
}

Tel: 96-27-543-2309 E-mail: akif_khasawneh@yahoo.com

Received: May 14, 2012 Accepted: June 4, 2013 Published: July 1, 2013

doi:10.5296/jmr.v5i3.3689 URL: http://dx.doi.org/10.5296/jmr.v5i3.3689

\begin{abstract}
This study investigates the relation between human resource management strategies (selection, training, evaluation, safety \& security, and motivation) as practiced at the public Relations department in the Government Ministries of Jordan and job loyalty (job). The study employed the questionnaire for data gathering and SPSS program for processing. A representative inclusive to all PR's employees $(\mathrm{N}=145)$ and major findings were:

1. Low satisfaction level among PR's employees regarding HRM strategies as practiced within their organizational units.

2. Low relationship $(M=2.57)$ between staff selection and recruitment methods and job desirability and retention.

3. Low relationship $(M=2.73)$ between training methods and job desirability \& retention

4. Low relationship $(\mathrm{M}=2.77)$ between motivation methods and job desirability \& retention

5. Low relationship $(\mathrm{M}=2.78)$ between evaluation methods and job desirability \& retention

6. Low relationship $(\mathrm{M}=2.89)$ between occupational safety measures and job satisfaction and retention
\end{abstract}


7. No statistically significant differences were found regarding the relation between HRM strategies and job desirability and retention by "Job Title".

8. There were statistically significant differences by gender in favor of female participants regarding the relation between HRM strategies and job satisfaction and retention excluding the motivation strategy that demonstrated no statistically significant differences for the females.

Keywords: HRM Strategies, PR's Units, Jordanian Government Ministries, Job Loyalty 


\section{Introduction}

One of most significant production elements is manpower because it forms a backbone of managerial functions and organizational activities without which no one of the organizational activities would succeed or prosper as human is the starting point as it is the endpoint of the organization's life cycle and survival including the different management levels both top, middle and bottom. Human resource management undertakes a critical role in organizations because its deals with humans which differ from other production elements in terms of characteristics, features, physiological disposition, social economic backgrounds, and cultural conditions. Under the behaviorism, managers shifted their more classical concern from the befits of employers towards employee-oriented approaches that seek to create common benefit for both employers and employees and respond to changes taking place in the internal and external environments, most importantly the changes in the characteristics of employees themselves. After all, employee in different managerial and technical places forms the hub of the institutional system and for managers serves as leverage to achieve the organizational goals.

No doubt that all organizational units including the management, financial, marketing, service and public Relations PR's take a significant part in the organizations and from a systematic approach should be dealt with carefully. However, PR's unit in any organization would take a little bit greater importance than other managerial units in that it combines managerial, technical and marketing functions together; and further the PR's officers serve as the frontal face of the organizations and reflect its image to both external environment (customers and competitors) and the internal environment (employees). Taking this in mind, Arab managers, particularly Jordanian organizations are advised to pay greater attention to human resource management HRM at their PR's units by focusing on strategic HRM practices related to staffing \& recruiting, training, motivating and evaluation which will would improve job performance and loyalty of PR's officers.

\subsection{Statement of the Problem}

The problem addressed by the current study stems from observations and experiences developed by this author that would indicate a low interest by Jordanian government organizations in the public relations function in the organizations, and low importance given to this function in the modern organizations. This reality was translated into low interest in the PR's employees in terms of staffing, recruiting, training, evaluation and incentives received in comparison with employees in other organizational units both managerial and technical. In consequence, job loyalty desirability and retention among PR's employees would be affected as a result, and they would like transfer to other jobs or seek a job in other organization provide them job security, estimation and justice.

\subsection{Study Questions}

1. To what level are PR's employees at the Jordanian government organizations satisfied with HRM strategies (staffing \&recruiting, training, evaluating, safety \& security, and motivating) in their organizational units? 


\section{MInstitute ${ }^{\text {Mnk }}$}

2. Is there a relationship between HRM strategies ((staffing \& recruiting, training, evaluating, safety \& security, and motivating) implemented at the PR's units in the Jordanian government organizations and job loyalty (job desirability and retention)?

3. Are there statistically significant differences between HRM strategies (staffing \&recruiting, training, evaluating, safety \& security, and motivating) and job loyalty (job desirability and retention)?

\subsection{Study Objectives}

The objective sought by the present study is multiple:

1. To identify the desirability level among PR's employees at the Jordanian government organizations regarding the HRM strategies (staffing \& recruiting, training, evaluating, safety \& security, and motivating).

2. To identify whether there exists a relationship between HRM strategies (staffing \& recruiting, training, evaluating, safety \& security, and motivating) and job loyalty (job desirability \& retention) among PR's employees in the Jordanian government organizations.

3. To identify whether there are statistically significant differences in the relation of HRM strategies (staffing \& recruiting, training, evaluating, safety \& security, and motivating) and job loyalty (job desirability \& retention) attributed to such demographics as gender and job title?

\subsection{Significance of the Study}

The significance of the present study resides in its attempt to highlight the basic part taken by human resource management HRM in the success of organization both public and private, because human component is essential for organizational success and excellence that once managed carefully and powerfully will produce far-reaching outcomes for different stakeholders, including:

1. PR's employees will benefit from results for this study that exported to reveal how satisfied they are regarding their jobs in reality.

2. Decision makers and top managers will find results from the present study meaningful because they would provide insights on how to interact with their PR's employees.

3. The public sector that seeks to improve competitiveness need improve employee performance through human resource management HRM strategies.

\subsection{Correlates}

This study included the following variables:

1. Independent variables: human resource management (HRM) strategy (staffing, recruiting, training, evaluation, safety and security, and motivating) 


\section{$\Lambda$ Macrothink}

2. Dependent variable: job loyalty (job desirability \& retention)

\subsection{Hypotheses}

1. Low desirability level among PR's employees at the government organization regarding HRM strategies (staff selection and recruitment, training, evaluation, safety and security, motivating).

2. There is statistically significant relation between human resource management strategies (staff selection and recruitment, training, evaluation, safety and security, motivating) as practiced at PR's units in the government organizations and job loyalty (job desirability \& loyalty).

3. There are statistically significant differences between human resource management strategies (staff selection and recruitment, training, evaluation, safety and security and motivating) and job loyalty (job desirability \& retention) by demographic characteristics of gender and job title.

\section{Methods}

Population consisted of all PR's employees at the central government ministries of Jordan located in metropolitan Amman counting (23) major ministry with (145) PR's employees. The study inclusively surveyed the PR's officers, and a questionnaire specifically designed for this purpose was administered to participants. Out of all questionnaires distributed (138) received back, and four found unusable were excluded. The final sample included 134 participants representing (92\%) of PR's officers population.

\subsection{Data Collection}

For data collection, the depended on the:

1. Secondary Resources: represented related references booth printed or electronic materials and reviewed the related books, literature and journals.

2. Primary Resources: Questionnaire specifically designed to meet the purpose of the current study and collect data from the PR's employees at the central government ministries in Jordan. The questionnaire is composed of three parts as follows:

Part One: collects information on the demographic characteristics of participants (gender and job title).

Part Two: Included items (1-5 questions) measuring desirability level of PR's employees at the central government ministries in Jordan regarding HRM strategies (Staffing, recruiting, training, evaluation, safety \& security, and motivating)

Part Three: Included items measuring the independent variable components regarding HRM strategies adopted at the PR's units in the Jordanian government organizations. The items were distributed to five themes; the first subscale (items 6-15) measured the relation of staffing and recruiting strategies with job desirability \& retention; the second subscale (items 16-25) measured the relation of training strategies on job desirability \& retention; third 
subscales (items 26-35) measured the relation of evaluation strategies with job desirability \& retention; subscale four (items 36-45) measured relation of occupational safety \& security measures with job desirability \& retention; and finally the thematic subscale six (items 46-55) measured the relation of motivating strategies with job desirability \& retention.

\subsubsection{Validity and Reliability Tests}

The questionnaire was sent to a number of experienced academies and specialists in Business Administration, and Statistics to verify validity of questionnaire content. There was general agreement regarding validity of the questionnaire for empirical administration on the condition of rewording some items, and delete lengthy items. The author conducted a pilot study on a sample of (35) employees out of population to determine intelligibility of questionnaire items and identify weaknesses from viewpoints of participants. As a result some items were reworded accordingly and necessary changes were made to achieve highest accuracy and intelligibility levels.

Internal consistency Chronbach alpha coefficient (91\%) was found appropriate for management research purpose regarding internal consistency and statistical analyses in this field (Sekaran, 2006).

\subsubsection{Statistical Analysis Methods}

The SPSS program was used for statistical treatments. Statistical analysis were conducted using percentages, ordinal means of relative importance by variables, standard deviations, T-test, one-way analysis of variance, and Scheffe post hoc comparisons for testing study hypotheses.

\section{Theoretical Framework}

\subsection{Conceptualization of HRM}

Over recent decades, human resource management has been differently designated by organization based on the industry where the organization operates. Many designations have emerged to indicate human resource management such as staffing units, personnel or employee management, human relations management, administrative affairs, manpower management, employee affairs management, industrial management and finally as Human Resource Management (HRM) that although differs in name only, it has many features that share in common with the former approaches regarding the essential functions of a human management unit that include recruiting appropriate manpower to the organization, employee reward and compensation, maintenance of employees and providing safe environment to them, personnel development and training, managing industrial relations, employee evaluation and motivating, and building a wide database of employee data in the organization (Al Barnoti, 2007, P. 35; Al Taai et al, 2009, P. 39).

Abbas and Ali (2003) identified four kinds of objectives for Human Resource Management:

1- Social Objectives: This kind of objectives responds to the community objectives by recruiting and employing individuals in different jobs depending on their competencies which 
helps the community develop and grow in different aspects. Typically, personnel management is affected by social limitations in the eternal environment such as legislations and regulations related to labor and laborers.

2- Organizational Objectives: The human resource management forms a subsystem of a wider system (organization), and functionally integrates with the other subsystems and organizational components. The organizational objectives of the human resource become evident through the line and staff functions.

3- Functional Objectives: These realize when the human resource performs specialized functions in serving employees throughout organizational levels depending on their needs.

4- Humanistic Objectives: Refer to helping individuals gratify their needs and desires because humans are essential for the productive process and a significant element of the production components.

Dissler (2003) described Human Resource Management as the study, analysis and procedures practiced by the HR unit in the organization to identify the organizational needs of employees, and staff selection based on specific criteria and use with them a set of professional development practices such as training, evaluation, job description, safety and security, rewards, and remuneration.

Edwin (1984) referred to human resource management as the practices targeting employees in the organization in terms of planning, directing, organizing, monitoring, recruiting, training, maintain job rights and privileges of employees, and protect them from risks related to work so as to achieve objectives on the individual, organization and community levels (Edwin, 1984, P. xiii).

Sison (1982) defined Human Resource Management "As the function of management concerned with promoting and enhancing the development of work effectiveness and advancement of the human resources in the organization through proper planning, organizing, directing ,coordinating and controlling of activities related to procurement, development, motivation and compensation of employees to achieve the goals of the enterprise.

Lado \& Wilson (1994) described human resource management (HRM) as "a set of distinct but interrelated with different functions and activities such as: attracting, training and developing, maintaining or disposing the employees of the organization".

\subsection{Related Studies}

Caliskan (2010) conducted a study in Turkey entitled "The impact of strategic human resource management on organizational performance" for purpose of identifying the effect of HRM strategies on the organizational performance and found that proper implementation of HRM practices yield sustainable competitive edge and improve employee performance level. The study also revealed a positive association between implementation of HRM strategies and performance level. 
Khan (2010) investigated the effect of HRM practices on the organizational performance in the oil and gas industry in Pakistan and found a positive association between implementation of HRM systems and job performance of employees. The study advised managers keep adopting clear HRM strategies that serve as essential reference to ensure effective performance.

Mukhtar, et al (2012) investigated the impact of HR practices on organizational citizenship behavior and mediating effect on organizational commitment in NGO of Pakistan. This study by focusing on training, development, rewarding employees, and empowerment found that training and empowerment highly impacted loyalty and organizational citizenship behavior; whereas recognition and acknowledgement of employee effort was the least impacting on employee loyalty and organizational citizenship behavior.

Rathnaweera (2010) questioned whether HRM Practices impact employee desirability, Commitment or Retention? For purpose of measuring effect of factors influencing employee's job desirability and loyalty in public sector banks in Sri Lanka and concluded that the factors most influencing job desirability and loyalty among employees were the rewarding systems, social benefits, then performance assessment and training.

Savaneviciene \& Stankeviciute (2011) was conducted in Lithuania on Human Resource Management Practices Linkage with organizational Commitment and job desirability, and found that the factors most creating job loyalty among employees and increase their desirability level were to encourage and motivate gifted, increase their participation in the managerial process and enhance their skills through the training programs and building good relations will all employees.

Syed \& Yan, (2012) investigated impact of high performance human resource management practices on employee job desirability in China to identify the possible effects of high performance human resource that have reflections on job desirability. The study such HRM practices as job empowerment, job rotation, merit-based participation, performance-based promotion, performance-based reward, and procedures to manage employee complaints. The study found that the variables considered by the study were significant and contribute to a high level of desirability, and seem to have impact on employee job description excluding procedures to manage employee complaints.

Prabhakart \& Ram (2011) conducted a study in Jordanian environment entitled "Antecedent HRM practices for organizational commitment" for purpose a number of HRM functions on job loyalty and concluded that employee loyalty was most influenced by the HRM practice that imply using clear job description and design, and continuous training of employees on their job tasks.

Imran and Ahmed (2012) investigated the impact of human resource practices on organizational commitment among service sector employees in Pakistan. The study of Imran and Ahmed (2012) on impact of human resource practices on the organizational commitment of the service sector employees of Pakistan. The study analyzed different of practices for human resources. The study revealed that all of the following practices: 
organization support, communication training and development, compensation, organizational climate, work life policies, career development opportunities, empowerment has a positive relationship with organizational commitment. Zaitouni, et al. (2012) studied the impact of Human Resource Management practices on organizational commitment in the banking sector in Kuwait.

The study investigated the impact of Human Resource Management (HRM) practices on the affective, continuance, and normative organizational commitment among employees in the banking sector in Kuwait. The results showed that fifty percent of the variables confirmed previous studies and the remaining fifty percent did not support these studies due to factors such as culture and values.

Ray and Ray (2011) investigated Human Resource Management practices and effects on employees' job desirability in selected small and medium sized iron \& steel firms in India and found that factors like performance appraisal, participation in decision making, training and development, empowerment, compensation influencing human resource management (HR) practices have significant association with job desirability (JS). In addition, performance appraisals, participation in decision making are found to have high positive impact on job desirability (JS). It has also been found that other elements like training and development, empowerment, compensation have substantial impact on employees' job desirability. But, job rotation, self-directed work teams, recruitment and selection have very negligible impact on job desirability as their respective statistics are insignificant.

\section{Statistical Analysis}

\subsection{Reliability}

To test for reliability, Chronbach internal consistency coefficient was computed within the range (.82-.87) as shown by table (1) and considered appropriate for purpose of the present study.

Table 1. Chronbach internal consistency of items by hypothesis and overall rating

\begin{tabular}{|l|c|}
\hline \multicolumn{1}{|c|}{ Area } & $\begin{array}{c}\text { Internal } \\
\text { Consistency }\end{array}$ \\
\hline Satisfaction Level & .83 \\
\hline $\begin{array}{l}\text { Relation between selection \& recruiting strategies and job desirability \& } \\
\text { retention }\end{array}$ & .87 \\
\hline Relation between training strategies and job desirability \& retention & .85 \\
\hline Relation between evaluation strategies and job desirability \& retention & .82 \\
\hline $\begin{array}{l}\text { Relation between occupational safety and security strategies and job } \\
\text { desirability \& retention }\end{array}$ & .84 \\
\hline Relation between motivating strategies and job desirability \& retention & .86 \\
\hline Total & .91 \\
\hline
\end{tabular}




\section{Macrothink}

Table 2. Frequencies and percentages by study variables

\begin{tabular}{|l|l|c|c|}
\hline \multicolumn{1}{|c|}{ Variable } & \multicolumn{1}{|c|}{ Category } & Count (Frequency) & Percentage\% \\
\hline \multirow{4}{*}{ Gender } & $\mathrm{M}$ & 85 & 63.4 \\
\cline { 2 - 4 } & $\mathrm{F}$ & 49 & 36.6 \\
\hline \multirow{4}{*}{ Educational Level } & Less than 30 yrs & 37 & 27.6 \\
\cline { 2 - 4 } & $30-40$ yrs & 61 & 45.5 \\
\cline { 2 - 4 } & 41 or more yrs & 36 & 26.9 \\
\cline { 2 - 4 } & Less than BA & 28 & 20.9 \\
\cline { 2 - 4 } & BA & 98 & 73.1 \\
\cline { 2 - 4 } & Graduate Studies & 8 & 6.0 \\
\hline \multirow{5}{*}{ Job Title } & Director & 15 & 11.2 \\
\cline { 2 - 4 } & Division Head & 46 & 34.3 \\
\cline { 2 - 4 } & Officer & $\mathbf{7 3}$ & $\mathbf{1 0 0 . 0}$ \\
\hline
\end{tabular}

\subsection{Hypotheses}

H1: "Low satisfaction level among PR's employees at the Jordanian government organizations regarding HRM strategies (staffing \& recruiting, training, evaluation, safety \& security, and motivating).

To verify accuracy of this hypothesis, means and standard deviations or items related to the first hypothesis were computed as shown in table below.

Table 3. Means and standard deviations of items regarding satisfaction level in descending order by means.

\begin{tabular}{|c|c|l|c|c|}
\hline Rank & No. & \multicolumn{1}{|c|}{ Item } & M & SD \\
\hline 1 & 3 & I believe that my HRM managers make honest evaluations & 2.50 & .891 \\
\hline 1 & 5 & $\begin{array}{l}\text { I am content with the rewarding systems initiated by the } \\
\text { HRM towards PR's offices at my unit }\end{array}$ & 2.50 & .891 \\
\hline 3 & 4 & $\begin{array}{l}\text { I am content with protective methods against smoking, } \\
\text { violence, job conflict, and stressors followed by HRM } \\
\text { managers in my workplace }\end{array}$ & 2.49 & .829 \\
\hline 5 & 2 & $\begin{array}{l}\text { HRM offers training programs to my unit } \\
\text { I am content with the staffing methods used by HRM } \\
\text { department to recruit qualified personnel }\end{array}$ & 2.44 & .854 \\
\hline 5 & 1 & \begin{tabular}{l} 
Satisfaction Level \\
\hline
\end{tabular} & 2.47 & .661 \\
\hline
\end{tabular}




\section{Macrothink}

Table (3) shows means and standard deviations of items regarding satisfaction level. The mean scores ranged between (2.40-2.50) with items ( 3 and 5) representing HRM strategies of motivating and evaluation were estimated top $(M=2.50)$, whereas item (1) representing HRM strategy of staffing \& recruiting in the last rank $(M=2.40)$ and the overall mean score of the first hypothesis was $(M=2.47)$. Mean score for each theme were benchmarked with the standard score (2.50), which is the benchmark at which to accept the hypothesis using T-test as shown by table (4).

Table 4. Means, standard deviations and T-test for items compared with the standard score (2.50).

\begin{tabular}{|l|c|c|c|c|c|c|}
\hline & Count & M & $\begin{array}{c}\text { Standard } \\
\text { Deviation }\end{array}$ & T-Value & $\begin{array}{c}\text { Freedom } \\
\text { Degrees }\end{array}$ & $\begin{array}{c}\text { Significance } \\
\boldsymbol{\alpha}\end{array}$ \\
\hline $\begin{array}{l}\text { Satisfaction } \\
\text { Level }\end{array}$ & 134 & 2.47 & .661 & -9.361 & 133 & .000 \\
\hline
\end{tabular}

The earlier table shows statistically significant differences at $(\alpha=.05)$ from the mean score and criterion score (3), where T-value (9.361) was statistically significant at (.000), thereby accepting this hypothesis

H2: There is statistically significant association between HRM strategies (staff selection and recruitment, training, evaluation, safety \& security, and motivation) employed at the PR's departments in the government organizations and job loyalty (job satisfaction and retention) among employees.

To verify this hypothesis, means and standard deviation were computed for items related the second hypothesis and results are shown by the following table.

1. Relation between staff selection \& recruitment methods and job desirability \& retention 


\section{Ml Macrothink}

Journal of Management Research

ISSN 1941-899X

2013, Vol. 5, No. 3

Table 5. Means and standard deviations of the relation between staff selection and recruitment strategies and job desirability $\&$ retention in descending order by means

\begin{tabular}{|c|c|l|c|c|}
\hline Rank & No. & \multicolumn{1}{|c|}{ Item } & M & SD \\
\hline 1 & 11 & $\begin{array}{l}\text { I am confident with the integrity and competency of HRM } \\
\text { department in recruiting new employees }\end{array}$ & 2.60 & .877 \\
\hline 1 & 12 & $\begin{array}{l}\text { HRM department raise awareness about a vacancy and introduce } \\
\text { applicants to related positives and negatives }\end{array}$ & 2.60 & .885 \\
\hline 1 & 13 & $\begin{array}{l}\text { HRM managers take opinion of employees before moving them to } \\
\text { other jobs. }\end{array}$ & 2.60 & 894 \\
\hline 4 & 14 & $\begin{array}{l}\text { I would like complete my service tenure before retirement at the } \\
\text { unite where I work }\end{array}$ & 2.59 & .768 \\
\hline 4 & 15 & $\begin{array}{l}\text { I would like complete my service tenure before retirement but other } \\
\text { units }\end{array}$ & 2.59 & .843 \\
\hline 6 & 10 & $\begin{array}{l}\text { HRM managers put the right person in the right place depending on } \\
\text { specialty, desire and experience }\end{array}$ & 2.58 & .904 \\
\hline 7 & 6 & $\begin{array}{l}\text { I so pleased to work for this organization } \\
\text { HRM department is careful about moving me to job which desirable } \\
\text { for me }\end{array}$ & 2.57 & .879 \\
\hline 9 & 7 & $\begin{array}{l}\text { I so pleased to work at the public relations unit } \\
\text { I appreciate highly my job in comparatively with other jobs }\end{array}$ & 2.51 & .829 \\
\hline 9 & 8 & $\begin{array}{l}\text { Relation between "staff selection \& recruitment" and "job } \\
\text { desirability \& retention }\end{array}$ & 2.57 & .605 \\
\hline & 9 & & .913 \\
\hline
\end{tabular}

Table (5) shows means and standard deviations or items related to the relation between staffing and recruitment strategy and job desirability and retention. Mean scores ranged between (2.51-2.60), where items (11, 12 and 13) "I am confident with the integrity and competency of HRM department in recruiting new employees", "HRM department raise awareness about a vacancy and introduce applicants to related positives and negatives" and "HRM managers take opinion of employees before moving them to other jobs" were placed top $(\mathrm{M}=2.60)$ while items (7 and 8) "I so pleased to work for this organization", and " I appreciate highly my job in comparatively with other jobs " were placed in the lowest rank $(\mathrm{M}=2.51)$, and the overall mean score of the relation between staffing \& recruiting strategy and job desirability and retention was low $(\mathrm{M}=2.57)$.

The mean score of the theme was compared with the standard score of (2.5)-hypothesis acceptance criterion-using T-test and table (6) shows the results. 
Table 6. Means, standard deviation and T-test results of items compared with criterion (2. 5)

\begin{tabular}{|l|c|c|c|c|c|c|}
\hline & Count & M & SD & T-Value & $\begin{array}{c}\text { Freedom } \\
\text { Degrees }\end{array}$ & $\begin{array}{c}\text { Significance } \\
\alpha\end{array}$ \\
\hline $\begin{array}{l}\text { Relation between "staff selection } \\
\text { \& recruitment" and "job } \\
\text { desirability \& retention " }\end{array}$ & 134 & 2.57 & .605 & $8.193-$ & 133 & .000 \\
\hline
\end{tabular}

The earlier table shows statistically significant differences at $(\alpha=.05)$ between the mean score and criterion score (3), where T-value (8.193) was statistically significant at (.000), thereby accepting this hypothesis.

2. Relation between training strategy and job desirability and retention

Table 7. Means and standard deviation of the relation between training strategy and job desirability $\&$ retention in descending order by means

\begin{tabular}{|c|c|l|c|c|}
\hline Rank & No. & \multicolumn{1}{|c|}{ Item } & M & SD \\
\hline 1 & 23 & HRM department adopts theoretical training approaches & 3.71 & .724 \\
\hline 2 & 20 & HRM department uses study and analysis to identify training needs & 3.02 & .897 \\
\hline 3 & 24 & $\begin{array}{l}\text { HRM department uses pre and post evaluations for training } \\
\text { outcomes }\end{array}$ & 2.63 & .872 \\
\hline 4 & 17 & $\begin{array}{l}\text { HRM department offers training programs that match my academic } \\
\text { background }\end{array}$ & 2.62 & .839 \\
\hline 5 & 16 & $\begin{array}{l}\text { HRM department offers training programs that directly related to } \\
\text { my job duties }\end{array}$ & 2.61 & .965 \\
\hline 5 & 18 & $\begin{array}{l}\text { HRM department allows job rotation opportunity for freshmen } \\
\text { employees }\end{array}$ & 2.61 & .909 \\
\hline 7 & 19 & $\begin{array}{l}\text { HRM department is careful about just selection of employees for } \\
\text { training programs }\end{array}$ & 2.60 & .942 \\
\hline 7 & 21 & $\begin{array}{l}\text { HRM department organize training courses to enhance ethical, } \\
\text { positive and quality-related behavior }\end{array}$ & 2.60 & .842 \\
\hline 9 & 22 & $\begin{array}{l}\text { HRM department focuses on training practical skills } \\
\text { HRM department offers undifferentiated training opportunities on } \\
\text { equal basis }\end{array}$ & 2.51 & .763 \\
\hline 10 & 25 & $\begin{array}{l}\text { Relation between training strategy and job desirability \& } \\
\text { retention }\end{array}$ & $\mathbf{2 . 7 3}$ & $\mathbf{. 5 9 0}$ \\
\hline
\end{tabular}

Table (7) shows means and standard deviations or items related to the relation between training strategy and job desirability and retention. Mean scores ranged from (2.51-3.71), where items (23) "HRM department adopts theoretical training approaches" was placed top 
$(\mathrm{M}=3.71)$ while item (25) "HRM department offers undifferentiated training opportunities on equal basis" was placed in the last rank $(\mathrm{M}=2.51)$, and the overall mean score of the relation between training strategy and job desirability \& retention was at $(M=2.73)$.

The mean score of the theme was compared with the standard score of (2.5)-hypothesis acceptance criterion-using T-test and table (8) shows the results.

Table 8. Means and standard deviations and T-test results of items compared with criterion (2.5)

\begin{tabular}{|l|c|c|c|c|c|c|}
\hline & Count & $\mathrm{M}$ & $\begin{array}{c}\text { Standard } \\
\text { Deviation }\end{array}$ & T-Value & $\begin{array}{c}\text { Freedom } \\
\text { Degrees }\end{array}$ & $\begin{array}{c}\text { Significance } \\
\alpha\end{array}$ \\
\hline $\begin{array}{l}\text { Relation between training } \\
\text { strategy and job desirability \& } \\
\text { retention }\end{array}$ & 134 & 2.73 & .590 & -5.201 & 133 & .000 \\
\hline
\end{tabular}

The earlier table shows statistically significant differences at $(\alpha=.05)$ between the mean score and criterion score (3), where T-value (5.201) was statistically significant at (.000), thereby accepting this hypothesis.

\section{Relation between evaluation strategy and job desirability \& retention}

Table 9. means and standard deviations of the evaluation strategy and job desirability \& retention in descending order by means

\begin{tabular}{|c|c|c|c|c|}
\hline Rank & No. & Item & M & SD \\
\hline 1 & 35 & Underestimating my performance motivates me work more & 3.69 & .665 \\
\hline 2 & 26 & $\begin{array}{l}\text { HRM department adopts scientific criteria for employee } \\
\text { evaluation }\end{array}$ & 3.06 & .839 \\
\hline 3 & 34 & $\begin{array}{l}\text { Employees are made aware to evaluation results and their opinions } \\
\text { and suggestions are carefully considered }\end{array}$ & 2.70 & .776 \\
\hline 4 & 33 & $\begin{array}{l}\text { HRM department has qualified staff to carry out employee's } \\
\text { performance assessments }\end{array}$ & 2.67 & .839 \\
\hline 5 & 30 & Impartial fair assessment methods are used & 2.66 & .859 \\
\hline 5 & 31 & Assessments are used to reward for creativity correct mistakes & 2.66 & .777 \\
\hline 7 & 32 & $\begin{array}{l}\text { Assessments are used for planning purpose to detect strengths, } \\
\text { weaknesses, opportunities and risks }\end{array}$ & 2.65 & .861 \\
\hline 8 & 27 & HR management implements assessment on individual basis & 2.56 & .889 \\
\hline 8 & 28 & HR management implements group assessments & 2.56 & .889 \\
\hline \multirow[t]{2}{*}{10} & 29 & HR management implements institutional assessments & 2.55 & .946 \\
\hline & & $\begin{array}{l}\text { Relation between evaluation strategy and job desirability \& } \\
\text { retention }\end{array}$ & 2.78 & .535 \\
\hline
\end{tabular}




\section{Macrothink}

Table (9) shows means and standard deviations or items related to the relation between evaluation strategy and job desirability and retention. Mean scores ranged from (2.55-3.69); where item (35) "Underestimating my performance motivates me work more" was placed top $(\mathrm{M}=3.69)$ while item (29) "HR management implements institutional assessments" was placed in the last rank $(\mathrm{M}=2.55)$, and the overall mean score of the relation between evaluation strategy and job desirability \& retention was at $(\mathrm{M}=2.78)$.

The mean score of the theme was compared with the standard score of (2.5)-hypothesis acceptance criterion-using T-test and table (10) shows the results.

Table 10. Means and standard deviations and T-test results of items compared with the criterion score (2.5)

\begin{tabular}{|l|c|c|c|c|c|c|}
\hline & Count & M & $\begin{array}{l}\text { Standard } \\
\text { Deviation }\end{array}$ & T-Value & $\begin{array}{c}\text { Freedom } \\
\text { Degrees }\end{array}$ & $\begin{array}{c}\text { Significance } \\
\boldsymbol{\alpha}\end{array}$ \\
\hline $\begin{array}{l}\text { Relation between } \\
\text { evaluation strategy and job } \\
\text { desirability \& retention }\end{array}$ & 134 & 2.78 & .535 & -4.859 & 133 & .000 \\
\hline
\end{tabular}

The previous table shows statistically significant differences $(\alpha=.05)$ between the mean score and criterion score (3) where T-value was (4.859) and statistically significant at (.000) thereby accepting this hypothesis.

\section{Relation between occupational safety strategies and job desirability \& retention}




\section{Macrothink}

Journal of Management Research

ISSN 1941-899X

2013, Vol. 5, No. 3

Table 11. Means and standard deviations of occupational safety strategies and job desirability $\&$ retention in descending order by means

\begin{tabular}{|c|c|l|c|c|}
\hline Rank & No. & \multicolumn{1}{|c|}{ Item } & M & SD \\
\hline 1 & 41 & $\begin{array}{l}\text { HR managers sympathize the sorrows and painful moments I } \\
\text { might experience }\end{array}$ & 3.56 & .741 \\
\hline 2 & 43 & I feel my organization provides job security for me and my family & 3.25 & .896 \\
\hline 3 & 42 & HR managers share rejoice moments with me & 3.21 & .672 \\
\hline 4 & 44 & $\begin{array}{l}\text { Inconvenient organizational climate motivates my search for } \\
\text { other job opportunity }\end{array}$ & 2.79 & .795 \\
\hline 5 & 45 & $\begin{array}{l}\text { HRM managers find solutions for employee problems amicably in } \\
\text { positive ways }\end{array}$ & 2.76 & .911 \\
\hline 6 & 39 & $\begin{array}{l}\text { HRM department provides clear job duties to protect employees } \\
\text { from stressors and task overlap }\end{array}$ & 2.71 & .891 \\
\hline 6 & 40 & $\begin{array}{l}\text { HRM department keeps improving workplace to save employees } \\
\text { from stressors }\end{array}$ & 2.71 & .883 \\
\hline 8 & 38 & $\begin{array}{l}\text { HRM department creates cooperation and synergy between } \\
\text { employees and top managers }\end{array}$ & 2.70 & .823 \\
\hline 9 & 37 & $\begin{array}{l}\text { HRM department promotes conscious regarding no-smoking } \\
\text { behaviors among employees }\end{array}$ & 2.64 & .835 \\
\hline 10 & 36 & $\begin{array}{l}\text { The unit where I work is a comfortable workplace } \\
\text { Relation between occupational safety \& security strategy and } \\
\text { job desirability \& retention }\end{array}$ & 2.62 & $\mathbf{2 . 8 9}$ \\
\hline $\mathbf{. 5 6 2}$ \\
\hline
\end{tabular}

Table (11) shows means and standard deviations of items related to the relation between the occupation safety \& security strategy and job desirability \& retention. Mean scores ranged between (2.62-3.56), where item (41) "HR managers sympathize the sorrows and painful moments I might experience" were placed top $(\mathrm{M}=3.56)$ while item (36) "The unit where I work is a comfortable workplace" was placed in the last rank $(\mathrm{M}=2.62)$, and the overall mean score of the relation between occupational safety \& security strategy and job desirability \& retention was at $(\mathrm{M}=2.89)$.

The mean score of the theme was compared with the standard score of (2.5)-hypothesis acceptance criterion-using T-test and table (12) shows the results. 
Table 12. Means and standard deviations and T-test results compared with criterion score (2.5)

\begin{tabular}{|l|l|l|l|l|c|c|}
\hline & Count & M & $\begin{array}{l}\text { Standard } \\
\text { Deviation }\end{array}$ & T-Value & $\begin{array}{l}\text { Freedom } \\
\text { Degrees }\end{array}$ & $\begin{array}{c}\text { Significance } \\
\boldsymbol{\alpha}\end{array}$ \\
\hline $\begin{array}{l}\text { Relation between } \\
\text { occupation safety \& } \\
\text { security strategy and job } \\
\text { desirability \& retention }\end{array}$ & 134 & 2.89 & .562 & -2.166 & 133 & .032 \\
\hline
\end{tabular}

The previous table shows statistically significant differences $(\alpha=.05)$ among the mean score and the criterion score of (3) where T value was (2.166) and statistically significant at (.032) thereby accepting the hypothesis.

\section{The relationship between motivating strategies and job desirability and retention.}

Table 13. Means and standard deviations of the relation between motivation strategies and job desirability and retention in descending order by means

\begin{tabular}{|c|c|l|c|c|}
\hline Rank & No. & \multicolumn{1}{|c|}{ Item } & M SD \\
\hline 1 & 54 & $\begin{array}{l}\text { Employees at my unit expect more benefits by moving to other } \\
\text { job }\end{array}$ & 3.19 & .845 \\
\hline 2 & 55 & My performance ties with rewards and benefits I gain & 3.15 & .619 \\
\hline 3 & 53 & $\begin{array}{l}\text { Individual creativity is rewarded with material or immaterial } \\
\text { compensation }\end{array}$ & 2.75 & .882 \\
\hline 4 & 52 & Incentives and rewards policy is just and equal & 2.73 & .869 \\
\hline 5 & 46 & $\begin{array}{l}\text { My organization has fair incentives and rewards systems for all } \\
\text { employees }\end{array}$ & 2.70 & .832 \\
\hline 6 & 51 & $\begin{array}{l}\text { Incentives and rewards are granted publicly and honestly } \\
\text { (n)entives and rewards are merit-based and given proportionately } \\
\text { with the performance accomplished }\end{array}$ & 2.66 & .894 \\
\hline 8 & 47 & $\begin{array}{l}\text { I receive incentives that proportionate with my performance level } \\
\text { Ibelieve that my organization adopts a rewarding system that has } \\
\text { equivalents in organization in the same industry }\end{array}$ & 2.63 & .863 \\
\hline 8 & 48 & $\begin{array}{l}\text { Rewarding systems are reviewed frequently in response to } \\
\text { changes taking place }\end{array}$ & 2.63 & .772 \\
\hline 8 & 49 & $\begin{array}{l}\text { Relation between motivating strategy and job desirability \& } \\
\text { retention }\end{array}$ & $\mathbf{2 . 7 7}$ & $\mathbf{. 5 4 3}$ \\
\hline
\end{tabular}

Table (13) shows means and standard deviations or items related to the relation between motivating strategy and job desirability and retention. Mean scores ranged between 
(3.19-2.63), where item (54) "Employees at my unit expect more benefits by moving to other job" was placed top $(\mathrm{M}=3.19)$ while items $(47,48$ and 49) "I receive incentives that proportionate with my performance level", "I believe that my organization adopts a rewarding system that has equivalents in organization in the same industry" and " Rewarding systems are reviewed frequently in response to changes taking place" were placed in the last rank $(\mathrm{M}=2.63)$, and the overall mean score of the relation between motivating strategy and job desirability \& retention was at $(\mathrm{M}=2.77)$.

The mean score of this theme was compared with the standard score of (2.5)-hypothesis acceptance criterion-using T-test and table (14) shows the results.

Table 14. Means, standard deviations and T-test results of items compared with the criterion score $(2.5)$

\begin{tabular}{|l|c|c|c|c|c|c|}
\hline & Count & M & $\begin{array}{c}\text { Standard } \\
\text { Deviation }\end{array}$ & T-Value & $\begin{array}{c}\text { Freedom } \\
\text { Degrees }\end{array}$ & $\begin{array}{c}\text { Significance } \\
\boldsymbol{\alpha}\end{array}$ \\
\hline $\begin{array}{l}\text { Relation between } \\
\text { motivating strategy and job } \\
\text { desirability \& retention }\end{array}$ & 134 & 2.77 & .543 & -4.802 & 133 & .000 \\
\hline
\end{tabular}

The previous tables shows statistically significant differences at $(\alpha=.05)$ level between mean estimates and the criterion score of (3), where T-value (4.802) was statistically significant at $(\alpha .000)$, meaning acceptance of the hypothesis.

H3: There are statistically significant differences between HRM strategies (staffing \& recruiting, training, evaluation, Safety \& security, and motivating) and job loyalty (job desirability \& retention) attributed to the demographic characteristics: gender, age, educational level and job title.

To verify hypothesis, means, and standard deviations of the association between HRM strategies (staffing \& recruiting, training, evaluation, Safety \& security, and motivating) and job loyalty (job desirability and retention) by study variables of gender, age, educational level and job title. To find out statistical significance of the means, T-test was employed with variable "gender", and ANOVA was used with each of the variables age, educational level, and job title as show in the below table.

\subsection{Demographic Characteristics}

\subsubsection{Gender}


Table 15. Means, standard deviations and T-test results of "Gender" effect

\begin{tabular}{|c|c|c|c|c|c|c|c|}
\hline Strategy & Qualification & Count & M & $\mathrm{SD}$ & T-Value & $\begin{array}{c}\text { Freedom } \\
\text { Degrees }\end{array}$ & $\begin{array}{c}\text { Significance } \\
\alpha \\
\end{array}$ \\
\hline \multirow{2}{*}{$\begin{array}{ll}\text { Staffing } & \& \\
\text { Recruiting } & \end{array}$} & $\mathrm{M}$ & 85 & 2.49 & .576 & \multirow[t]{2}{*}{-2.005} & \multirow[t]{2}{*}{132} & \multirow[t]{2}{*}{.047} \\
\hline & $\mathrm{F}$ & 49 & 2.71 & .635 & & & \\
\hline \multirow[t]{2}{*}{ Training } & $\mathrm{M}$ & 85 & 2.64 & .560 & \multirow[t]{2}{*}{-2.565} & \multirow[t]{2}{*}{132} & \multirow[t]{2}{*}{.011} \\
\hline & $\mathrm{F}$ & 49 & 2.90 & .609 & & & \\
\hline \multirow[t]{2}{*}{ Evaluation } & M & 85 & 2.71 & .526 & \multirow[t]{2}{*}{-1.863} & \multirow[t]{2}{*}{132} & \multirow[t]{2}{*}{.065} \\
\hline & $\mathrm{F}$ & 49 & 2.89 & .538 & & & \\
\hline \multirow[t]{2}{*}{ Safety \& Security } & M & 85 & 2.82 & .586 & \multirow[t]{2}{*}{-1.985} & \multirow[t]{2}{*}{132} & \multirow[t]{2}{*}{.049} \\
\hline & $\mathrm{F}$ & 49 & 3.02 & .500 & & & \\
\hline \multirow[t]{2}{*}{ Motivating } & $\mathrm{M}$ & 85 & 2.70 & .524 & \multirow[t]{2}{*}{-2.049} & \multirow[t]{2}{*}{132} & \multirow[t]{2}{*}{.042} \\
\hline & $\mathrm{F}$ & 49 & 2.90 & .558 & & & \\
\hline
\end{tabular}

Table (15) shows statistically significant differences at $(\alpha=.05)$ attributed to gender effect on all human resource management HRM strategies excluding motivation strategy, where differences were in favor of females.

\subsubsection{Job Title}

Table 16. Means and standard deviations by Job Title

\begin{tabular}{|c|c|c|c|c|}
\hline & Category & Count & $\mathbf{M}$ & SD \\
\hline \multirow{4}{*}{$\begin{array}{l}\text { Relation between staffing \& recruiting strategy and job } \\
\text { desirability \& retention }\end{array}$} & Director & 15 & 2.42 & .658 \\
\hline & $\begin{array}{l}\text { Division } \\
\text { Head }\end{array}$ & 46 & 2.59 & .581 \\
\hline & Officer & 73 & 2.59 & .613 \\
\hline & Total & 134 & 2.57 & .605 \\
\hline \multirow{4}{*}{$\begin{array}{l}\text { Relation between training strategy and job desirability \& } \\
\text { retention }\end{array}$} & Director & 15 & 2.48 & .594 \\
\hline & $\begin{array}{l}\text { Division } \\
\text { Head }\end{array}$ & 46 & 2.77 & .622 \\
\hline & Officer & 73 & 2.76 & .565 \\
\hline & Total & 134 & 2.73 & .590 \\
\hline \multirow{4}{*}{$\begin{array}{l}\text { Relation between evaluation strategy and job desirability } \\
\text { \& retention }\end{array}$} & Director & 15 & 2.57 & .607 \\
\hline & $\begin{array}{l}\text { Division } \\
\text { Head }\end{array}$ & 46 & 2.78 & .501 \\
\hline & Officer & 73 & 2.82 & .538 \\
\hline & Total & 134 & 2.78 & .535 \\
\hline Relation between occupational safety \& security & Director & 15 & 2.53 & .560 \\
\hline
\end{tabular}




\begin{tabular}{|l|l|c|c|c|}
\hline strategy and job desirability \& retention & $\begin{array}{l}\text { Division } \\
\text { Head }\end{array}$ & 46 & 2.98 & .522 \\
\cline { 2 - 6 } & Officer & 73 & 2.92 & .566 \\
\cline { 3 - 6 } & Total & 134 & 2.89 & .562 \\
\hline $\begin{array}{l}\text { Relation between motivating strategy and job } \\
\text { desirability \& retention }\end{array}$ & Director & 15 & 2.64 & .585 \\
\cline { 2 - 6 } & $\begin{array}{l}\text { Division } \\
\text { Head }\end{array}$ & 46 & 2.82 & .510 \\
\cline { 3 - 6 } & Officer & 73 & 2.78 & .557 \\
\hline & Total & 134 & 2.77 & .543 \\
\hline
\end{tabular}

Table (16) demonstrates surface variance in the means and standard deviations due to variability of job title categories. To demonstrate significance of mean differences, one way analysis of variance was computed and results are shown in table (17).

Table 17. One way analysis of variance regarding Job Title effect

\begin{tabular}{|c|c|c|c|c|c|c|}
\hline & Source & $\begin{array}{c}\text { Total } \\
\text { Squares }\end{array}$ & $\begin{array}{l}\text { Freedom } \\
\text { Degrees }\end{array}$ & $\begin{array}{c}\text { Mean } \\
\text { Squares }\end{array}$ & F-Value & $\begin{array}{c}\text { Significance } \\
\alpha\end{array}$ \\
\hline \multirow{3}{*}{$\begin{array}{l}\text { Relation between } \\
\text { staffing \& recruiting } \\
\text { strategy and job } \\
\text { desirability } \\
\text { retention }\end{array}$} & Intergroup & .389 & 2 & .194 & .527 & .591 \\
\hline & Intra-group & 48.323 & 131 & .369 & & \\
\hline & Overall & 48.712 & 133 & & & \\
\hline \multirow{3}{*}{$\begin{array}{l}\text { Relation between } \\
\text { training strategy and } \\
\text { job desirability \& } \\
\text { retention }\end{array}$} & Intergroup & 1.056 & 2 & .528 & 1.527 & .221 \\
\hline & Intra-group & 45.308 & 131 & .346 & & \\
\hline & Overall & 46.364 & 133 & & & \\
\hline \multirow{3}{*}{$\begin{array}{l}\text { Relation between } \\
\text { evaluation strategy } \\
\text { and job desirability } \\
\& \text { retention }\end{array}$} & Intergroup & .770 & 2 & .385 & 1.351 & .263 \\
\hline & Intra-group & 37.319 & 131 & .285 & & \\
\hline & Overall & 38.089 & 133 & & & \\
\hline \multirow{3}{*}{$\begin{array}{l}\text { Relation between } \\
\text { occupational safety } \\
\& \text { security strategy } \\
\text { and job desirability } \\
\& \text { retention }\end{array}$} & Intergroup & 2.327 & 2 & 1.164 & 3.838 & .024 \\
\hline & Intra-group & 39.719 & 131 & .303 & & \\
\hline & Overall & 42.046 & 133 & & & \\
\hline \multirow{3}{*}{$\begin{array}{l}\text { Relation between } \\
\text { motivating strategy } \\
\text { and job desirability } \\
\text { \& retention }\end{array}$} & Intergroup & .367 & 2 & .183 & .619 & .540 \\
\hline & Intra-group & & & & & \\
\hline & Overall & & & & & \\
\hline
\end{tabular}


Table (17) shows no statistically significant differences at $(\alpha=.05)$ attributed to current position for all variables excluding the relation between occupational safety strategy and job desirability \& retention. To demonstrate whether paired differences between the means were statistically significant, Scheffee post hoc comparisons were used as shown in table (18).

Table 18. Scheffee post hoc comparisons by Job Title

\begin{tabular}{|c|c|c|c|c|c|}
\hline & & M & Director & $\begin{array}{l}\text { Division } \\
\text { Head }\end{array}$ & Officer \\
\hline \multirow{3}{*}{$\begin{array}{l}\text { Strategic relation between the occupational } \\
\text { safety and job satisfaction \& retention }\end{array}$} & Director & 2.53 & & & \\
\hline & $\begin{array}{l}\text { Division } \\
\text { Head }\end{array}$ & 2.98 & $.45^{*}$ & & \\
\hline & Officer & 2.92 & .38 & .07 & \\
\hline
\end{tabular}

* Statistically significant at $(\alpha=.05)$

Table (18) shows statistically significant differences at $(\alpha=.05)$ between job titles "Director" and "Division Head", where differences were favoring "Division Head".

\section{Results}

- There is general low satisfaction level among employees regarding HRM strategies of staffing \& recruiting, training; evaluation, safety \& security, and motivating with mean score ranging between (2.40-2.50). Staffing \& recruiting strategy was placed top $(M=2.40)$ regarding low satisfaction level.

- Low level of job desirability and retention among PR's officers, and results showed perceived tendency PR's employees to move to other jobs in the organization.

- Low level of training opportunities that are provided on equal basis for PR's officers in comparison with employees in other jobs in the organizations under study.

- Low interest level of the human resource management with the institutional evaluation.

- Low interest level of human resource management at the PR's units as to provision of a comfortable environment for the employees.

- Low level of rewards system equality for employees at the PR"s units in comparison with PR's units in other organizations.

- There were no statistically significant differences regarding the relation between HRM strategies and job desirability and retention by job title; whereas the study found statistically significant differences by gender which was in favor of females regarding the relation of HRM strategies with job desirability and retention, excluding the motivating strategy that showed no statistically significant differences for the females themselves. 


\section{Recommendations}

Based on the realer results, the author suggests the following recommendations:

- Top managers at the government organizations are advised to take strict control on the HRM practices to ensure best implementation in harmony with the organizational strategies.

- It is necessary to restructure HRM units at the government organizations under study so as to ensure providing them with qualified employees with sufficient competencies and develop their skills both from academic and practical aspects since HRM units take main responsibility on professional development of the employees in the organization.

- HRM department need to operate cooperatively and harmoniously with the different organizational units in a balanced way.

- HRM needs to provide employees a comfortable environment where they can enjoy a degree of occupation safety and security.

- Employees at the PR's units should be honestly rewarded and compensated taking into account their counterparts in other organizational units.

\section{References}

Abbas, Suhaila Mohammad, \& Ali, Ali Hussein. (2003). Human Resource Management, $3^{\text {rd }}$ Edition, Dar Wael Publishers \& Distributors, Amman.

Al Barnooti, Suad. (2007). Human Resource Management. 3rd Edition, Dar Wael Publishers \& Distributors, Amman

Attai, Yousef, Al Aqel, Moayad, \& Al Abbadi, Hashem. (2009). Human Resource Management: Integrated Strategic Approach, Al Waraq Publishers \& Distributors, Amman.

Caliskan, Esra Nemli, (2010). The impact of strategic human resource management on organizational Performance, Journal of Naval science and engineering, 2,100-116

Dessler, Gary, (2003). Human Resource management, 9th edition, prentice-Hall, New Jersey Edwin, Flippo (1984).Personnel Management, Mc Graw-Hill Book Company, New York.

Eslami, Noo shin, \& Nakhaie, Hamid. (2011). Effects of human Resource Management Activities to Improve innovation In Enterprises, 3rd International conference on Information and financial Engineering, IPEDR, 12, IACSIT Press, Singapore.

Imran, Asma, \& Ahmed, Mehboob. (2012). Impact of Human Resource Practices On Organizational Commitment: A Study Among Service Sector Employees, Interdisciplinary Journal Of Contemporary Research In Business, 4(2), 81-90.

Khan, Muhammad Asif. (2010). Effect of Human Resource management practice on organizational performance-An Empirical study of oil and Gas industry in Pakistan, international of journal of economies, Finance and administrative sciences Eurojournalls, $24,157-175$. 


\section{1) Macrothink}

Journal of Management Research

ISSN 1941-899X

2013, Vol. 5, No. 3

Lado, A. A., \& Wilson, M. (1994). Human Resource systems and sustained competitive Advantage: A Competence Based perspective, Academy of Management Review, 19, 699-727.

Mukhtar, Sial,Muhammad Adnan;Imran,Ali, \& jilani,syed Mukhtar Ahmad. (2012). Impact of HR practices of organizational commitment in NGO of Pakistan, World Applied sciences journal, 18(7), 961-908.

Peabhakar, Guantusala, \& Ram, Padmakumar. (2011). Antecedent HRM practices for organizational commitment, International journal of business and social science, 2, 55-62

Rathanweera, Ragama Rathnweerage. (2010). Do HRM practices impact employee's satisfaction, commitment or Retention? (Empirical Studies of Sri Lankan public sector Banks), Master thesis, University of Agder, Department of business administration, Sri Lanka.

Ray, Sarbapriya, \& Ray, Ishita Aditya. (2011). Human Resource Management Practices and Its Effect on Employees' Job Satisfaction: A Study on Selected Small and Medium Sized Iron \&Steel Firms in India, Public Policy and Administration Research, 1(1).

Savaneviciene, Asta, \& Stankeviciute, Zivile. (2011). Human Resource Management Practices Linkage with organizational commitment and job satisfaction, ISSN 182206515, Economics and management, 16, 921-928. Available at www.Ktu.iy/iy/mokslas/zurnalai/ekovad/16/18-6515-2011-0921.Pdf.

Sekaran, Uma. (2006). Research Methods for Managers: a Skill-Building Approach, New York: John Willey and Sons.

Sison, Perfecto. (1982) Personnel and human Resource development, 5th. Edition. Re \& Book store, Manila, Philippines.

Syed, Nausheen, \& Yan, Lin Xiao. (2012). Impact of high performance human resource management practices on employee job satisfaction: Empirical Analysis. Interdisciplinary journal of contemporary research business, 4(2).318-341.

Smeenk, S. G.A., Eisinga, R.N., Teelken, J.C., \& Doorewaard, J. A. C. M. (2006). The Effects of HRM Practices and antecedents on organizational commitment among university employees, Int. Journal of Human Resource Management, 17(12), 2035-2054. http://dx.doi.org/10.1080/09585190600965449

Zaitouni, Michel. Sawalha, Nabeel, \& ElSharif, Adil. (2012). The Impact of Human Resource Management Practices on Organizational Commitment in the Banking Sector in Kuwait, International Journal of Business and Management, 6(6). http://dx.doi.org/10.5539/ijbm.v6n6p108 